\title{
Effect of transforming growth factor- $\beta 2$ on biological regulation of multilayer primary chondrocyte culture
}

\author{
Seyed Ali Behruz Khaghani · Gunay Akbarova • Chin Fhong Soon • \\ Gulrukh Dilbazi
}

Received: 22 February 2018/Accepted: 15 October 2018/Published online: 30 October 2018

(C) The Author(s) 2018

\begin{abstract}
Cytokines are extremely potent biomolecules that regulate cellular functions and play multiple roles in initiation and inhibition of disease. These highly specialised macromolecules are actively involved in control of cellular proliferation, apoptosis, cell migration and adhesion. This work, investigates the effect of transforming growth factor-beta2 (TGF$\beta 2$ ) on the biological regulation of chondrocyte and the repair of a created model wound on a multilayer culture system. Also the effect of this cytokine on cell length, proliferation, and cell adhesion has been investigated. Chondrocytes isolated from knee joint of rats and cultured at 4 layers. Each layer consisted of $2 \times 10^{5}$ cells $/ \mathrm{ml}$ with and without TGF- $\beta 2$. The expression of mRNA and protein levels of TGF- $\beta$ receptors and Smad1, 3, 4, and 7 have been analysed
\end{abstract}

S. A. B. Khaghani

Faculty of Engineering and Informatics, University of Bradford, Bradford, UK

G. Akbarova $(\square)$

Department of Genetics and Theory of Evolution, Faculty of Biology, Baku State University, Baku, Azerbaijan e-mail: akperova_science@mail.ru

C. F. Soon

Biosensor and Bioengineering Laboratory, MiNT-SRC

Research Center, Tun Hussein Onn University of

Malaysia, Batu Pahat, Johor, Malaysia

G. Dilbazi

The Laboratory of Veterinary Preparations, The

Veterinary Scientific-Research Institute, Baku, Azerbaijan by RT-PCR and western blot analysis. The effect of different supplementations in chondrocyte cell proliferation, cell length, adhesion, and wound repair was statistically analysed by One-way ANOVA test. Our results showed that the TGF $\beta 2$ regulates mRNA levels of its own receptors, and of Smad3 and Smad7. Also the TGF- $\beta 2$ caused an increase in chondrocyte cell length, but decreased its proliferation rate and the wound healing process. TGF- $\beta 2$ also decreased cell adhesion ability to the surface of the culture flask. Since, TGF- $\beta 2$ increased the cell size, but showed negative effect on cell proliferation and adhesion of $\mathrm{CHC}$, the effect of manipulated TGF- $\beta 2$ with other growth factors and/or proteins needs to be investigated to finalize the utilization of this growth factor and design of scaffolding in treatment of different types of arthritis.

Keywords Chondrocyte - Cytokines - TGF- $\beta 2$. Gene expressions · Wound repair - Multilayer cell culture

$\begin{array}{ll}\text { Abbreviations } \\ \text { IL-1 } & \text { Interleukin-1 } \\ \text { TGF- } \beta & \text { Transforming growth factor- } \beta \\ \text { GDF-5 } & \text { Growth and differentiation factor-5 } \\ \text { ePPi } & \text { Extracellular inorganic pyrophosphate } \\ \text { PKC } & \text { Protein Kinase C } \\ \text { R-Smads } & \text { Receptor-regulated Smads } \\ \text { BSA } & \text { Bovine serum albumin }\end{array}$




$\begin{array}{ll}\text { bFGF } & \text { Basic fibroblast growth factor (bFGF) } \\ \text { FGF-2 } & \text { Fibroblast growth factor-2 } \\ \text { ECM } & \text { Extra-cellular matrix } \\ \text { RA } & \text { Rheumatoid arthritis } \\ \text { SFBs } & \text { Synovial Fibroblasts } \\ \text { DMEM } & \text { Dulbecco's modified eagle's medium } \\ \text { HBSS } & \text { Hank's balanced salt solution } \\ \text { RT-PCR } & \text { Real time-polymerase chain reaction } \\ \text { FCS } & \text { Fetal calf serum } \\ \text { ELISA } & \text { Enzyme-linked immunosorbent assay } \\ \text { ACI } & \text { Autologous chondrocyte implantation } \\ \text { RAC } & \text { Rat articular chondrocytes (RAC) } \\ \text { HAC } & \text { Human articular chondrocyte (HAC) }\end{array}$

\section{Introduction}

Cartilage degeneration caused by injuries and congenital abnormalities is a great clinical challenge (Gillogly et al. 1998). Damage to cartilage results an incomplete wound healing and can be followed by progressive and chronic lesions (Bhosale and Richardson 2008). Cartilage can be injured by tears, general wear or injury resulting from genetic factors or overuse of tissue during sport (McIlwraith 2007).

Damage to the cartilage does initiate a reparative response (Meyer and Wiesmann 2006). However, deep cartilage defects result in the loss of noncollagenous matrix (Meyer and Wiesmann 2006) which requires complete tissue repair and in more severe cases when the lesion is in the fibrillar network and involves significant cell death the cartilage does not heal (Cubinskaya et al. 2008). In contrast if a lesion occurs in the collagenous matrix, there is a degree of regeneration. In this case treatment of cartilage by a cell therapy method and engineered tissue could enhance tissue repair (Cohen et al. 1992).

Cytokines are group of macromolecules synthesized by cells in response to immune stimuli to regulate the cell's function (Galvani and Cowley 1992). They exert their effects on the same cells (autocrine activity) or on the neighboring cells (paracrine activity) by interacting with specific receptors (Balkwill 2000; Kermani and Pham 2001). Cytokines act as signaling proteins, and like hormones play an important role in pathophysiological and homeostatic processes such as fever, wound healing, inflammation, tissue repair and fibrosis. They are very active in regulation of cell function such as proliferation, migration, and matrix synthesis (Maitre et al. 2007). Some diseases such as degeneration of intervertebral disks could be caused by altering the expression of cytokines such as Interleukin-1 (IL-1) (Raftery and Sutherland 2002). Therefore investigation the role of cytokines in the development of diseases could be helpful in the therapy of some disorders.

Transforming growth factor- $\beta$ (TGF- $\beta$ ) superfamily includes a large group of soluble extracellular proteins which regulate the development in both vertebrates and invertebrates (Krauss 2006; Soo et al. 2000). TGF- $\beta$ family regulates the cell functions such as migration, apoptosis, proliferation and differentiation (Stoff et al. 2007; Soo et al. 2000; Spagnoli et al. 2007).

Transforming growth factor- $\beta$ (TGF- $\beta 1,2$, and 3 ) has been implicated in the ontogenetic transition from scarless fetal repair to adult skin repair with scaring. Fibromodulin which is a member of the small leucinerich proteoglycan family has been suggested as a biologically significant mediator of fetal scarless repair (Han et al. 2007; Cailotto et al. 2007). There is evidence that fibromodulin may be a biologically relevant modulator of TGF- $\beta$ activity during scar formation (Tchetina et al. 2006). Spagnoli et al. (2007) studied the role of transforming growth factor $\beta$ (TGF$\beta$ ) signalling in mice lacking the TGF- $\beta$ type-II receptor gene in their limbs. They found that TGF- $\beta$ receptor II signalling regulates growth and differentiation factor-5 (GDF-5) and joint morphogenic gene expression (Okazaki et al. 1996). Han et al. (2007) also studied the effect of transforming growth factor- $\beta 1$ on regulation of fibronectin isoform expression and splicing factor SRp40 expression during pro-chondrogenic cell line (ATDC5) chondrogenic maturation. Their report showed that the effects of TGF- $\beta 1$ on fibronectin isoform splicing during chondrogenesis may be largely dependent on its effect on SRp40 isoform expression (Thorp et al. 1992).

Cailotto et al. (2007) examined the production of extracellular inorganic pyrophosphate (ePPi) in chondrocytes and the signalling pathways involved in the regulation of Ank gene expression by TGF- $\beta$. The outcome of their research shows that the TGF- $\beta$ increases ePPi level, mainly by the induction of the Ank gene, which requires activation of $\mathrm{Ca}^{2+}$ - 
dependent Protein Kinase C (PKC) pathways in chondrocytes (Yamashita et al. 2002). Mutations in the Ank gene were reported in autosomal dominant craniometaphyseal dysplasia and ankylosing spondylitis, supporting a key role for the Ank gene in the field of mineralizing arthropathy (Galvani and Cowley 1992; Kaiser et al. 2004).

Biological effect of TGF- $\beta$ are mediated by two different serine/threonine kinase receptors, named T $\beta R I$ and T $\beta R I I$ and important for inducing signal transduction. T $\beta R I$ phosphorylates the receptor-regulated Smads (R-Smads) Smad2 and Smad3, which bind to Smad4, translocate into the nucleus and regulate gene expression in concert with other transcriptional factors (Davidson et al. 2005). Like R-Smads, the inhibitory Smad7 interacts with the activated T $\beta$ RI receptor. In contrast to $\mathrm{Smad} 2 / 3$, Smad7 forms a stable association with the receptor complex and prevents receptor-mediated phosphorylation of pathway-restricted Smads, resulting in disruption of TGF $\beta$ signaling. TGF- $\beta$ signalling pathway plays a critical role for maintenance of tissue homeostasis, and modification of TGF- $\beta$ signaling gene expression may be a cause for articular diseases such as osteoarthritis (OA) (Oka et al. 2007). Smad3 gene mutations are associated with the pathogenesis of it (Pohlers et al. 2007). In addition, osteoarthritis is associated with modifications of T $\beta$ RII and Smad7 expression (Ferguson and O'Kane 2004).

Tchetina et al. (2006) examined the effect of TGF$\beta 2$ on collagen cleavage on human osteoarthritic cartilage (Gorvy et al. 2005). Before Tchetina et al., Okazaki et al. (1996) studied the effects of transforming growth factor beta-1, beta- 2 and basic fibroblast growth factor (bFGF) on articular chondrocytes obtained from immobilised rabbit knees. However, they did not use TGF-beta 3 . They reported that the TGF beta- 1 or TGF beta- 2 in combination with bFGF exerted synergistic effects on cell proliferation in articular chondrocytes obtained from the rabbit. Their results suggest a critical role of cytokine combinations in the development of articular cartilage degeneration after immobilisation (Liu et al. 2014). Thorp et al. (1992) reported on the effects of transforming growth factor-beta 1, -beta 2 and -beta 3 in cartilage and bone cells during endochondral ossification in the chick. They discovered that TGF-beta localization controlled an increase in type II collagen and mRNA expression in transitional chondrocytes, suggesting a role for
TGF-beta in the induction of synthesis of extracellular matrix (Khaghani et al. 2012).

Yamashita et al. (2002) used fibroblast growth factor-2 (FGF-2) to determine severity of joint disease in Adjuvant-Induced arthritis in rats. Their results suggested that FGF-2 modulated disease progression, but did not affect initiation of the arthritis (Sefat et al. 2016).

As shown above there are many reports regarding using of various cytokines, growth factors and developed chondrocyte culture methods to stimulate the chondrocyte proliferation in vivo and in vitro. However, until now there are very few reports looking at the effect of the transforming growth factor beta family of cytokines (TGF- $\beta 1$, TGF- $\beta 2$ and TGF- $\beta 3$ ) on chondrocyte cell-cell and cell-ECM adhesion, cell proliferation, migration and wound healing.

Davidson et al. (2005) investigated the change of transforming growth factor-beta signalling in cartilage of old mice and found that the TGF- $\beta 2$ and 3 were reduced in 2 year old mice in comparison to 5 months old animals. The conclusion of their reports shows that the TGF-beta appears to play an important role in repair of cartilage and a lack of TGF-beta responsiveness in old mice might be at the root of osteoarthritis (Zheng et al. 2016).

Oka et al. (2007) used TGF- $\beta 2$ to examine the role of TGF- $\beta$ signalling in regulation of chondrogenesis and osteogenesis during mandibular development. Their data suggested that there are differential signal flows in response to TGF- $\beta$ control of chondrogenesis and osteogenesis during mandibular development (Lawrence 2001).

Pohlers et al. (2007) published a paper about upregulation of the transforming growth factor- $\beta$ pathway in rheumatoid arthritis (RA). They reported that the pathogenetic role of TGF- $\beta$-induced effects on Synovial Fibroblast (SFBs) in RA (Docagne et al. 2004).

The importance of transforming growth factors in wound healing has caused significantly increase in research on these types of cytokines.

Related work was also carried out by Mark Ferguson and O'Kane (2004) who identified some TGF- $\beta 1$ related therapeutic targets. They found that the growth factor profiles differ significantly in embryonic and adult tissue. For example, levels of TGF- $\beta 1$ and TGF- $\beta 2$ in embryonic wounds are very low, however the levels of TGF- $\beta 3$ is much higher in 
comparison to adult wounds (Van der Kraan and Van den Berg 2008). Similarly, Gorvy et al. (2005) found that by inhibiting TGF- $\beta 1$ and TGF- $\beta 2$, whilst simultaneously increasing TGF- $\beta 3$ concentrations in adult wounds, near embryonic repair could be achieved in adults (Yao et al. 2003).

Noticeably significant research on chondrocyte adhesion is lacking. In this work cell response in terms of cell phenotype, adhesion, alignment, wound healing capacity and secretion of extracellular matrix molecules will be examined in relation to exposure to TGF- $\beta 2$ in multiple 2 dimensional (Multilayer 3D) culture systems.

\section{Materials and methods}

Primary chondrocyte culture

Six neonate Sprague-Dawley rats were euthanized according schedule-1 of euthanasia. The Hyaline cartilages from knee joints were harvested, and their extracellular matrix was digested for $45 \mathrm{~min}$ at $37{ }^{\circ} \mathrm{C}$ using $15 \mathrm{ml}$ Trypsin EDTA-0.25\% and $10 \mathrm{ml}$ Collagenase type-II (Sigma Aldrich, UK). The cell suspension was centrifuged at $550 \mathrm{~g}$ to separate the cells from solution. The supernatant was discarded and the cell pellte were re-suspended in $5 \mathrm{ml}$-high glucose Dulbecco's modified eagle's medium (DMEM) (Sigma Aldrich, UK) with $1 \%$ L-glutamine supplementation. In $5 \mathrm{ml}$ cell suspension $14 \times 10^{5}$ cells were counted using a haemocytometer, giving a cell density of $2.8 \times 10^{5}$ cells $/ \mathrm{ml}$. The cell suspension was kept in a $15 \mathrm{ml}$ centrifuge tube and incubated at $37{ }^{\circ} \mathrm{C}$ until preparation of a TGF- $\beta 2$ solution.

Addition of this growth factor to the culture media facilitated the investigation of the effects of TGF- $\beta 2$ on the chondrocyte cell length, proliferation rate, cell adhesion and on wound repair of the created wound model.

All results from each part of the experiment were standardised using the setting of the initial cell density as $100 \%$ and then comparing the remaining cells with initial percentage. Standard error $( \pm$ SE) is also used to estimate any error in measurements and to determine the accuracy of the results.
Reconstitution of TGF- $\beta 2$

TGF- $\beta 2$ is a multifunctional peptide soluble in acid solvent. It is also soluble in water; however, the solution would be sticky and difficult to aliquot and utilise. It is also evident that TGF- $\beta 2$ requires a carrier molecule such as BSA to enable cell uptake by cell (Spagnoli et al. 2007). Several TGF- $\beta 2$ with different concentrations $(5,10$ and $50 \mathrm{ng} / \mathrm{ml})$ were used previously in our research while measuring the percentage of wound closure for chondrocyte mono and multilayers. Therefore a stock solution of $5 \mu \mathrm{g} / \mathrm{ml}$ TGF- $\beta 2$ was made by dissolving $2 \mu \mathrm{g}$ of TGF- $\beta 2$ in $400 \mu \mathrm{l}$ of sterile $4 \mathrm{mM} \mathrm{HCl}$ containing $1 \mu \mathrm{g} / \mathrm{ml} \mathrm{BSA}$ (Spagnoli et al. 2007; Zhang et al. 2007).

\section{Primary chondrocyte culture}

The experiment consisted of five tissue culture flasks labeled as Control, $\mathrm{HCl}, \mathrm{HCl} / \mathrm{BSA}, \mathrm{BSA}$ and TGF- $\beta 2$. A total of $2.88 \times 10^{5}$ cells per culture flask were subjected to this set of experiments. By resuspending this amount of cells into $5 \mathrm{ml}$ cell culture media, each culture flask is supposed to have a cell density of $5.76 \times 10^{4}$ cells $/ \mathrm{ml}$.

A total of $5 \mathrm{ml}$ of cell suspension were poured into the culture flask labeled as control. A total of $10 \mu \mathrm{l}$ of $4 \mathrm{mM} \mathrm{HCl}$ was added into another $5 \mathrm{ml}$ cell suspension labeled as $\mathrm{HCl} .10 \mu \mathrm{l}$ of BSA solution, dissolved in sterilised distilled water with a concentration of $1.5 \mu \mathrm{g} / \mathrm{ml}$, added into $5 \mathrm{ml}$ cell suspension and poured into the cell culture flask labeled as BSA. Another $5 \mathrm{ml}$ cell suspension was supplemented with $10 \mu \mathrm{l}$ of $4 \mathrm{mM} \mathrm{BSA} / \mathrm{HCl}$ prepared earlier and transferred into the culture flask named as $\mathrm{BSA} / \mathrm{HCl}$. The final $5 \mathrm{ml}$ cell suspension was supplemented with $10 \mu$ TGF- $\beta 2$ solution, poured into the culture flask labeled as TGF$\beta 2$ and incubated at $37{ }^{\circ} \mathrm{C}$ with another four culture flasks. Every $24 \mathrm{~h}$ the cell cultures were checked and imaged using a phase-contrast microscope with $10 \times$ magnification. The images were saved for future reference. Also, every $48 \mathrm{~h}$, the media were aspirated, discarded and replaced with fresh media with the same (10 $\mu \mathrm{l} / \mathrm{ml} \mathrm{v} / \mathrm{v}$ ) TGF- $\beta 2$ supplementation (Fig. 1).

The experiment was repeated three times to obtain significant data for statistical analysis. 


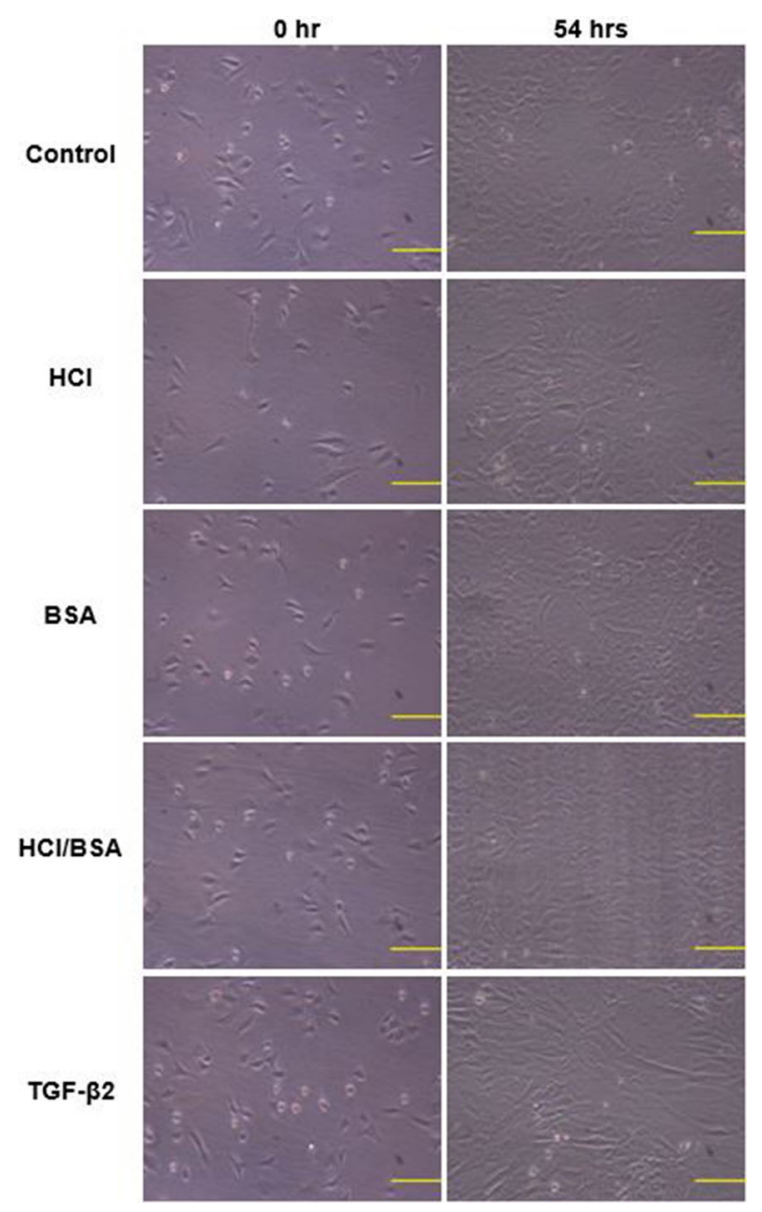

Fig. 1 The chondrocytes cultured in media with different supplementations. The captured images are the first and last pictures (scale bar $50 \mu \mathrm{m}$ )

\section{Measurement of cell length}

Cell-length measurements of all cell cultures supplemented with BSA, BSA/HCl, control and TGF- $\beta 2$ were performed $12 \mathrm{~h}$ after cell seeding into the tissue culture flasks. This time allowed for primary chondrocytes settling and attaching to the solid surface.

Recording of the cell length continued every $24 \mathrm{~h}$. A total of 30 randomly selected cells were imaged and saved and their lengths measured using NIH Image J software. As the primary chondrocytes were isolated from different zones of cartilage they had different shapes, and hence the largest dimension of the cells was considered as the cell length. The average data coming from repeated experiments were calculated and set as average chondrocyte cell length. The mean cell length and standard deviation with error bars were calculated using Microsoft Excel. The standardised cell lengths from each treatment were compared with the standardised dimension of chondrocytes in the control culture to find out whether or not TGF- $\beta 2$ causes any change in the length of the cells.

Following standardisation of the data, the first measurements were set as $100 \%$ and the subsequent data were determined as percentage average.

\section{Wound closure assay}

All five chondrocyte cultures reached $100 \%$ confluency after $132 \mathrm{~h}$.

The wound repair capacity of multilayer primary chondrocyte culture was investigated using model wound closure assay. A wound model was created by scratching the cell layer using a fine-tip extended transfer pipette of $1 \mathrm{~mm}$ diameter (Sigma Aldrich, UK). Following scratching, wound width was measured via Image $\mathbf{J}$ software every $2 \mathrm{~h}$ at 10 different points along the width until the wound was totally healed except for the model wound treated with TGF$\beta 2$, which did not fully heal during the experiment. The re-identification of these points was achieved by drawing 10 lines perpendicular to the scratch in the cell layer on the underside of the culture flask with an alcohol-resistant marker pen. Measurements of wound width were then taken to the right of the point at which each perpendicular line intersected with the model wound. An average wound width of $\sim 131.77 \mu \mathrm{m}$ was recorded and the normalized \% model wound closure was used to eliminate different wound width along the wound bed, for future analysis regarding the effect of different growth factor.

\section{Primary chondrocyte detachment analysis}

The strength of primary-chondrocyte attachment on substrate in the presence of different supplementations was analysed using the trypsinisation assay.

Trypsin is a temperature-dependent digestive enzyme which breaks down the cell-extracellular matrix and cell-cell binding proteins at the carboxyl end (Sigma Aldrich, UK). The cleavage of adhesion proteins results in cell detachment from substratum and/or separation from other cells.

The assay was carried out at room temperature of $18{ }^{\circ} \mathrm{C}$. The media were aspirated from the tissue culture flask and the flask was rinsed three times with 
Hank's balanced salt solution (HBSS) to remove any serum from the confluent layer of cells. After aspiration of the last HBSS, $2 \mathrm{ml}$ of trypsin was poured into the culture flask to detach the cells from the culture flask and their ECM. The protein digestion process was imaged by phase-contrast microscope, with a digital camera installed on the microscope, and Image J (NIH) software. A sequence of 60 images with 10-s time intervals were recorded and saved for further analysis.

A total of $2 \mathrm{ml}$ of serum containing media was added to the cell suspension immediately after detachment of the cell from the culture flask. After trypsinization, the suspension was used for cell count.

The time taken for the chondrocytes to get a round shape and shiny appearance, signs of detachment, was recorded.

The recorded time was multiplied by 10 , which was the time interval, and then divided by 60 to obtain the detachment time per second. The time taken for the detaching of a cell in the control culture was converted to percentage average as $100 \%$ and the other cell cultures, containing different supplementations, were compared against the control. Microsoft Excel was used to calculate the mean, standard deviation and a graph was then plotted to demonstrate $\%$ detachment time for each supplementation (Fig. 2).

The final suspensions obtained from trypsinisation were used to evaluate cell proliferation rate. This proliferation rate was achieved by counting the trypsinized cells and comparing with initial seeded cells.

\section{RNA extraction}

Total RNA was extracted from primary chondrocyte cultures using TRIzol Reagent (Invitrogen, UK). Samples $(2 \mu \mathrm{g})$ were treated with DNaseI and revers transcribed in a $25 \mu 1$ volume reaction using Superscript II enzyme (Invitrogen, UK) and random hexamer primers. Products were diluted 1:100 and stored at $-20{ }^{\circ} \mathrm{C}$ until used for RT-PCR (real time PCR).

\section{RT-PCR}

Primers were used at $5 \mu \mathrm{M}$ with $10 \mu \mathrm{l}$ of SYBR Green Master Mix (Thermo Fischer, UK) in final volume of $20 \mu \mathrm{l}$ under the following condition: $95{ }^{\circ} \mathrm{C}$ for $15 \mathrm{~min}$

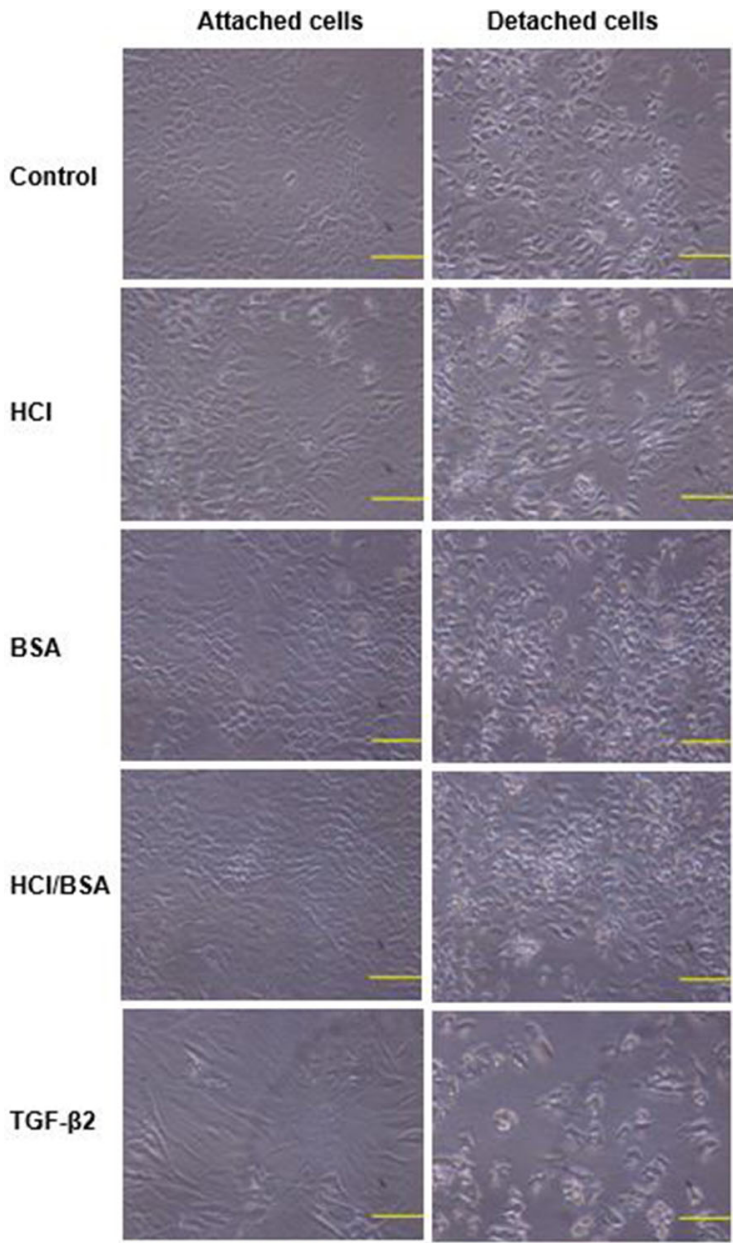

Fig. 2 Trypsinisation assay before (left) and after (right) detachment (scale bar $=50 \mu \mathrm{m})$

(denaturation), 45 cycles at $94{ }^{\circ} \mathrm{C}$ for $15 \mathrm{~s}, 60{ }^{\circ} \mathrm{C}$ for $20 \mathrm{~s}$ (annealing) and $72{ }^{\circ} \mathrm{C}$ for $20 \mathrm{~s}$ (amplification). PCR amplification and real-time fluorescence detection were performed by the Light Cycler version 1.0 detection system (Roche). Relative expression was calculated according to the $2^{-\Delta \Delta C t}$ method (Livak and Schmittgen 2001) (Table 1).

\section{Western blot analysis}

Cells were rinsed, and scrapped in RIPA lysis buffer (25 mM TrisHCl pH 7.6, $150 \mathrm{mM} \mathrm{NaCl}, 1 \%$ NP-40, $1 \%$ sodium deoxycholate, $0.1 \%$ SDS, Thermo Scientific, UK), supplemented with phosphatase and protease inhibitors (Thermo Scientific Halt Protease Inhibitor Cocktail, Halt ${ }^{\mathrm{TM}}$ Phosphatase Inhibitor 
Table 1 Utilized primers for RT-PCR amplification

\begin{tabular}{|c|c|c|}
\hline Gene & Forward primer & Revers primer \\
\hline Smad2 & $5^{\prime}$-GCTGTTTTCCTAGCGTGGCTT-3' & $5^{\prime}$-TCCAGACCCACCAGCTGACT- $3^{\prime}$ \\
\hline Smad3 & 5'-GCATCAGCCGCTTCTCAAGT-3' & 5'-АТСТССССАССАТСАССТСС-3' \\
\hline Smad4 & 5'-CCTTCTGGAGGAGATCGCT-3' & $5^{\prime}$-TCAATGGCTTCTGTCCTGTGG-3' \\
\hline Smad7 & 5'-AATGTGTTTTCTAGATTCCCAACTTCTT-3' & 5'-CACTCTCGTCTTCTCCTCCCAGTA-3' \\
\hline TGF- $\beta 2$ & $5^{\prime}$-CAGCGCTACATCGATAGCAA- $3^{\prime}$ & 5'-GGTCCTCAGTGTAGCCCAAG-3' \\
\hline T $\beta R I$ & $5^{\prime}$-TTAAAAGGCGCAACCAAGAAC- $3^{\prime}$ & 5'-GTGGTGATGAGCCCTTCGAT-3' \\
\hline TßRII & $5^{\prime}$-GACATCAATCTGAAGCATGAGAACA-3' & $5^{\prime}$ - GGCGGTGATCAGCCAGTATT-3' \\
\hline
\end{tabular}

Cocktail). The extracts (50 $\mu \mathrm{g}$ protein) were subjected to fractionation in $10 \%$ SDS-PAGE, transferred to polyvinylidene fluoride membranes (Kinesis, UK), and reacted with T $\beta$ RI, T $\beta$ RII (1:500), Smad $2 / 3$ or phospho-Smad $2 / 3$ polyclonal antibodies (1:1000) (Thermo Fisher Scientific, UK). Blocking buffer was added to each membrane and $0.5 \mu \mathrm{g} / \mathrm{ml}$ Pierce Goat anti-Rabbit IgG Secondary Antibody Horseradish Peroxidase (HRP) (Thermo Fisher, UK) was diluted in the blocking buffer (1:3000). The signals were revealed with SuperSignal West Pico Chemiluminescent Substrate (Thermo Fisher Scientific, UK) and exposed to X-ray film. The membranes were also reacted with anti $\beta$-actin to verify equal loading.

Statistical analysis

The effect of different supplementations in chondrocyte cell proliferation, cell length, adhesion, and wound repair was statistically analysed by One-way ANOVA test. This test was performed to evaluate the statistically significant difference between the means of the treatments. The difference between the means of the treatments was assumed as $\mathrm{Ha}$, and the similarity was assumed as $\mathrm{H}_{0}$.

$\mathrm{H}_{0}:$ Mean $1=$ Mean2 $=$ Mean3 $=$ Mean4

Statistical significance was determinated by student's test. $p$ values less than 0.05 were considered significant.

\section{Results}

Primary chondrocytes, cultured in multilayer in highglucose DMEM media supplemented with $10 \%$ FCS, were used as control culture.
The evaluation of the effect of different supplementations in chondrocyte proliferation showed that the $\mathrm{HCl}$ induced cell proliferation at the highest level (unpublished work) with $1026.23 \%$ increase (Fig. 3).

In contrast, TGF- $\beta 2$ induced apoptosis rather than proliferation. The cell density was lowered at 50.7\% when compared with control and the proliferation rate was 2.33 -fold. Unlike TGF- $\beta 2, \mathrm{HCl}$ induced cell proliferation at the highest level, which was 2.23 -fold more than control (Figs. 3, 4).

The cells treated with TGF- $\beta 2$ developed a wellspread fibroblastic shape acquiring a mean length of $14.20 \mu \mathrm{m}$ in diameter. This indicates that TGF- $\beta 2$ increases excessive synthesis of ECM proteins conclusion which are involved in the formation of fibroblast-type morphology and consequently dedifferentiation of chondrocyte in vitro. In comparison, $\mathrm{HCl}(12.2 \mu \mathrm{m} \pm 0.002 \mathrm{SE}), \mathrm{BSA}(11.18 \mu \mathrm{m} \pm 0.002$ $\mathrm{SE}), \mathrm{BSA} / \mathrm{HCl}(10.45 \mu \mathrm{m} \pm 0.002 \mathrm{SE})$ had no effect on cell length and cells under these treatment regimens resembled in the control treatment group $(12.51 \mu \mathrm{m} \pm$ $0.002 \mathrm{SE})$. There was no recognisable difference in

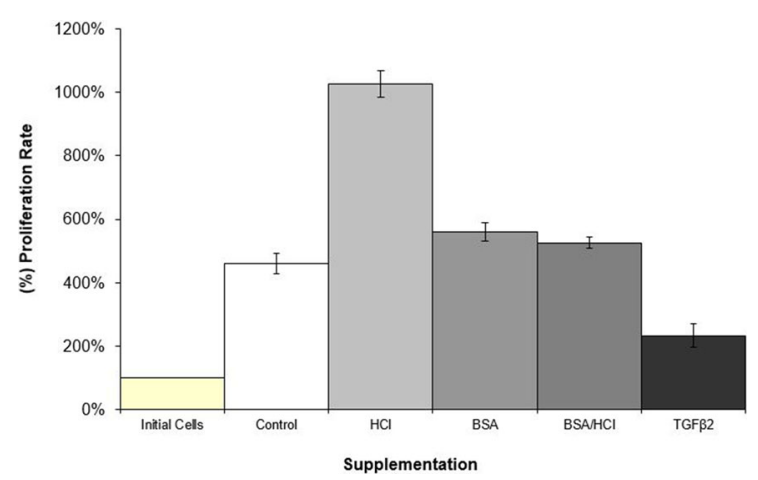

Fig. 3 Graph of primary chondrocyte proliferation cultured in DMEM media in various supplementations. Initial cell concentration, which was $2.8 \times 10^{5}$ cells $/ \mathrm{ml}$, was set as $100 \%$ 


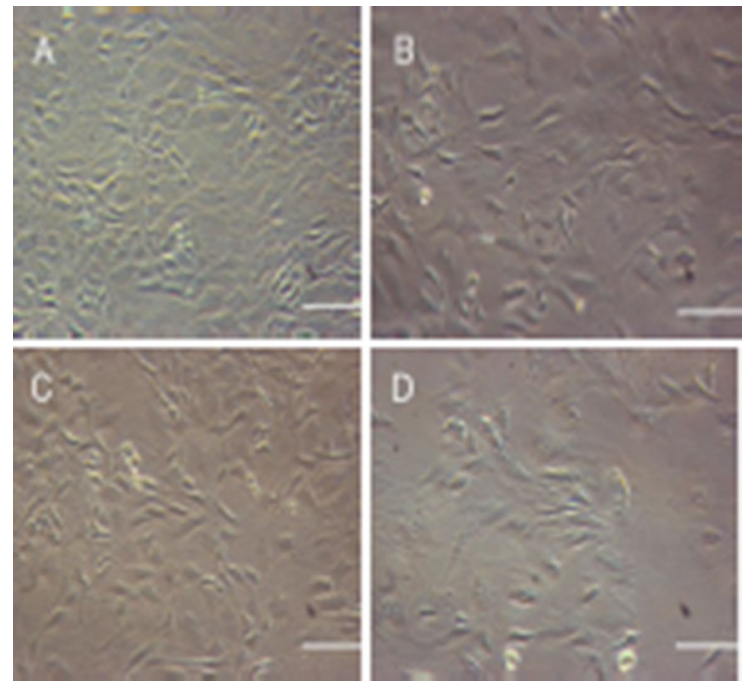

Fig. 4 Culture of chondrocyte cells in high glucose DMEM with different supplementations: a $\mathrm{HCl}$; b BSA; $\mathbf{c} \mathrm{BSA} / \mathrm{HCl}$, and d BSA/HCl/TGF- $\beta 2($ scale bar $=50 \mu \mathrm{m})$

cell morphology between $\mathrm{HCl}, \mathrm{BSA}, \mathrm{BSA} / \mathrm{HCl}$ and control (Fig. 4).

Another four culture environments with addition of $\mathrm{HCl}, \mathrm{BSA}, \mathrm{BSA} / \mathrm{HCl}$ and TGF- $\beta 2$ were compared against the control culture (Fig. 5).

Interestingly, each cell culture reached its largest cell length after different times.

TGF- $\beta 2$ increased the chondrocyte cell length up to $152.9 \%$ over a period of $132 \mathrm{~h}$. This could be related to an increase in the production of components of the ECM, which in turn, via up or down regulation of specific integrins, induced changes in chondrocyte shape. It is well known that the cytoskeleton determines the cell shape by anchoring to the integrin via the actin filament. ELISA could determine the type of integrin binding to the ECM/ligands. In contrast, the

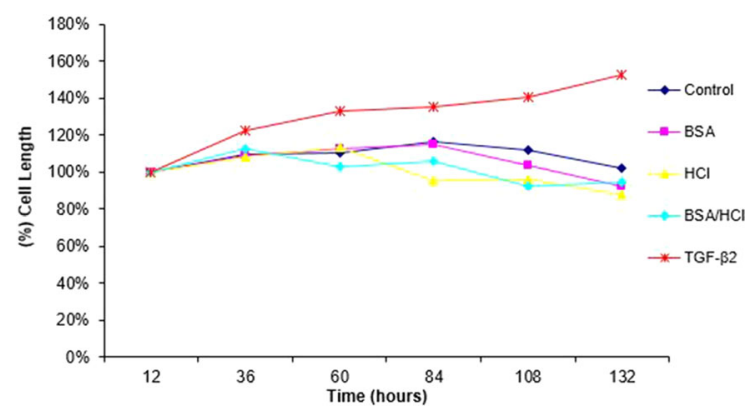

Fig. 5 Graphs of primary chondrocyte cell length during 132-h culture with various supplementations with standard error bar smallest cell length was observed in $\mathrm{BSA} / \mathrm{HCl}$ contained media with $112.85 \%$ increase and $10.45 \mu \mathrm{m}$. The average change of cells in their widest dimension in control was $115.97 \%$ with $12.51 \mu \mathrm{m}$. Only chondrocytes cultured in the TGF- $\beta 2$ contained medium demonstrated an almost constant increase in cell length with all others showing irregular changes. This is because of low-proliferation capacity of chondrocyte in the presence of TGF- $\beta 2$ as revealed in determination of the effect of TGF- $\beta 2$ on cell proliferation. The initial cell density was set as $100 \%$ and all other cultures were compared with this initial setting. The proliferation rate of control culture was $460.35 \%$, corresponding to a 4.6 -fold increase in cell density at the end of the experiment.

During $54 \mathrm{~h}$ model wound closure assay, only in controls and $\mathrm{HCl}$ contained culture was the gap completely closed (Fig. 6).

The fastest wound healing occurred in an acidic medium with $10 \mu \mathrm{l} 4 \mathrm{mM} \mathrm{HCl}$. The application of BSA/HCl/TGF $\beta-2$ and the application of BSA containing media appeared to inhibit wound closure. Initially, cell migration was detected circa $6 \mathrm{~h}$ after scratching. This may suggest that the chondrocyte cell requires a revitalisation time after mechanical stress in the form of scratching.

The results of model wound closure assays were set as a normalized percentage average. The outcomes were used to plot a graph to demonstrate the comparison of the wound closures of chondrocytes cultured in multilayer with various supplementations. It can be seen that the wound models of control and $\mathrm{HCl}$ contained cultures were closed at a slower rate after $54 \mathrm{~h}$ and those supplemented with BSA $(2.88 \mu \mathrm{m} \pm$ $0.4 \mathrm{SE}), \mathrm{BSA} / \mathrm{HCl}(1.38 \mu \mathrm{m} \pm 0.4 \mathrm{SE})$, and TGF- $\beta 2$ $(0.33 \mu \mathrm{m} \pm 0.1 \mathrm{SE})$ closed completely, after $54 \mathrm{~h}$ but at a faster rate, with almost complete closure (wound closure $\sim 98 \%$ ) after $\sim 30 \mathrm{~h}$ (Fig. 7).

Results from trypsinisation assay demonstrated the time required for detachment of chondrocyte cells from substrate and separation from each other. This time shows the strength of cell-substrate and/or cellcell adhesion (Fig. 2).

Chondrocytes cultured in the presence of $1 \% \mathrm{v} / \mathrm{v}$ of $4 \mathrm{mM} \mathrm{HCl}$ were detached in $7.778 \mathrm{~min}$, which corresponds to being $6.87 \%$ longer than control culture. This time for TGF $\beta-2$ was the lowest with $5.056 \mathrm{~min}$, which caused the cells to detach $2.22 \mathrm{~min}$ faster than the cells in the control culture. The cells in 

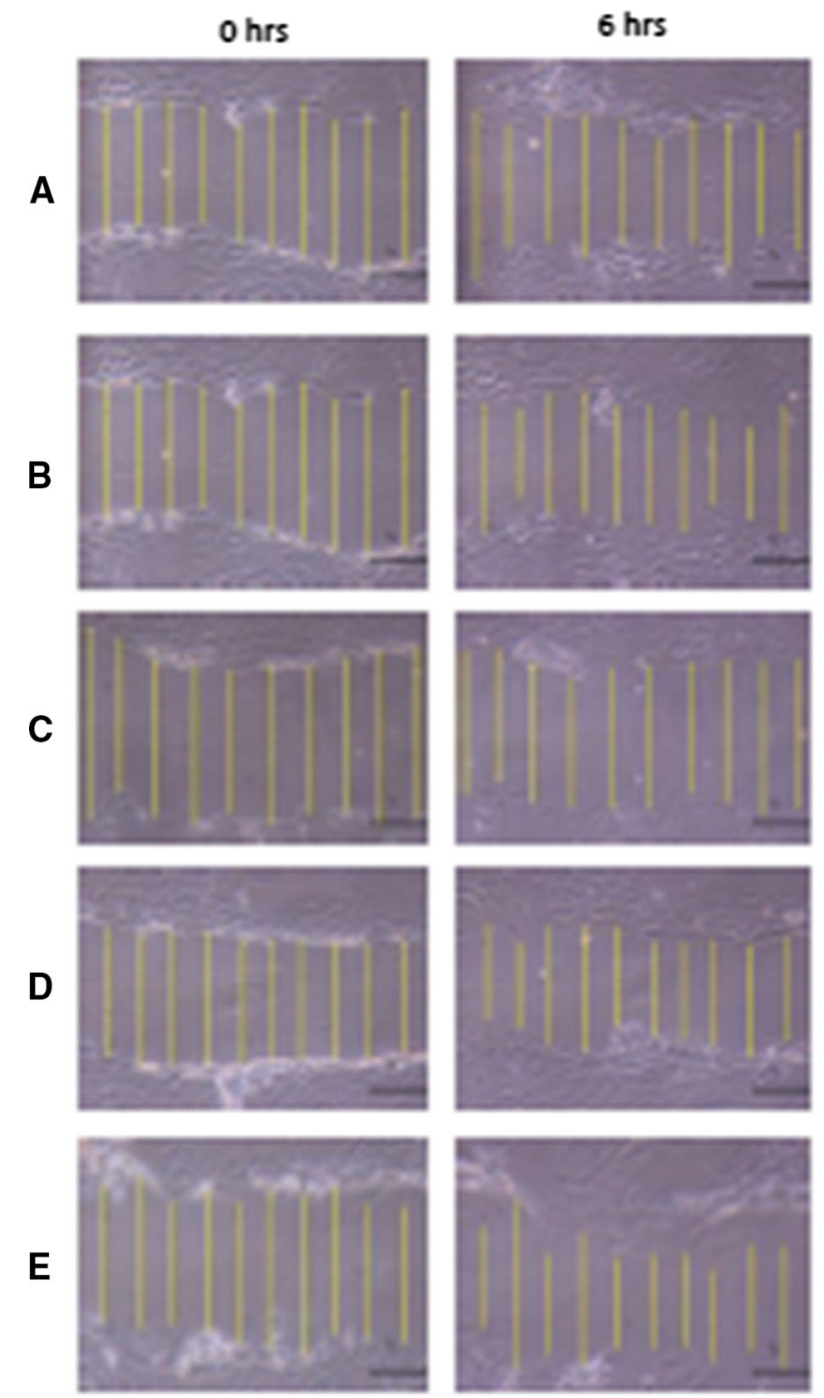

54 hrs
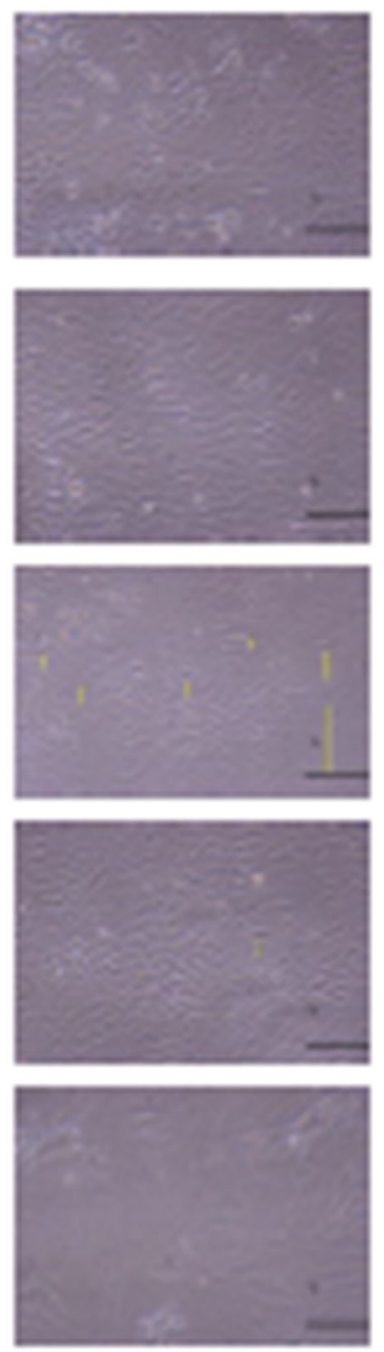

Fig. 6 Microphotographs of wound closure assay for primary chondrocyte: a control; b HCl; $\mathbf{c} \mathrm{BSA} ; \mathbf{d} \mathrm{BSA} / \mathrm{HCl}$, and e TGF $\beta$ 2. Multilayer cultures were scratched by tip of a plastic pipette of

BSA and BSA/HCl contained mediums showed recognisable reductions in detachment time of 5.94 and $6.05 \mathrm{~min}$, respectively.

It can be seen that TGF- $\beta 2$ addition resulted in lower \% detachment $(\sim 70 \%)$ whereas the $\mathrm{HCl}$ showed a similar result to control followed by BSA and $\mathrm{BSA} / \mathrm{HCl}$ additions with $\sim 85 \%$ detachment.

The above set of experiments revealed that TGF $\beta-2$ has an inhibitory effect on chondrocyte cell proliferation and reduces cell density in the presence of $10 \%$ FCS in planar culture system. This type of growth factor induces an increase in cell length by synthesis of
$1 \mathrm{~mm}$ and measured using image analysis software. An average wound size of $\sim 131.77 \mu \mathrm{m}$ was recorded after initial scratch at $0 \mathrm{~h}($ scale bar $=50 \mu \mathrm{m})$

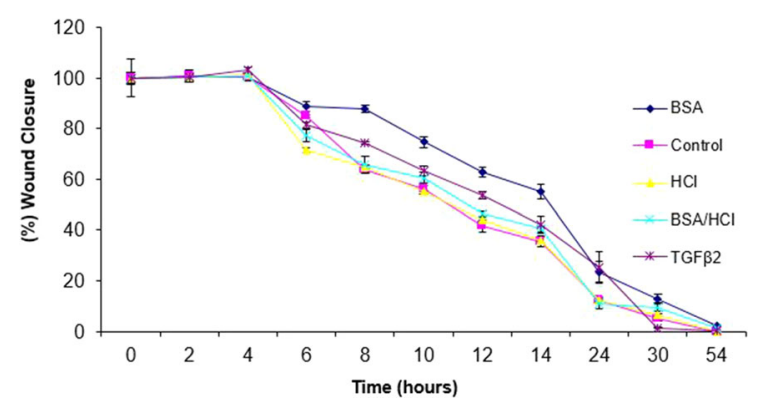

Fig. 7 , Graph of wound closure for primary chondrocytes cultured in $\mathrm{BSA}, \mathrm{BSA} / \mathrm{HCl}, \mathrm{HCl}$, and TGF- $\beta 2$ contained media and control 
extracellular matrix proteins and by stimulating the cell to acquire fibroblastic morphology. Excessive ECM molecules capture a large area in the culture flask and consequently cause the cells to spread well in multilayer with weak cell adhesion ability. In contrast, $1 \% \mathrm{v} / \mathrm{v} 4 \mathrm{mM} \mathrm{HCl}$ contained media promoted cell proliferation up to 10.12 -fold, which is very close to the required cell density for ACI.

The results of statistical analysis revealed that the null hypothesis was rejected in all tests, as in all tests the $\mathrm{F}>$ Fcrit and the $p<0.05$, except for wounds repair, which showed that the model wounds on the chondrocyte multilayers with different supplementations were almost similar in terms of wound closure response even after $54 \mathrm{~h}$ (Fig. 7).

We investigated the effect of TGF- $\beta 2$ on mRNA expression of TGF- $\beta$ signalling genes in a dosedependent manner, using real-time RT-PCR. A 48-h incubation with TGF- $\beta 2$ significantly reduced the expression of both TGF- $\beta$ receptors and Smad3, whereas the Smad7 mRNA level was increased. No significant effect was observed on Smad2 and Smad4 (Fig. 8a).

A time-course study revealed that, at mRNA levels, TGF- $\beta 2$ quickly upregulates its own receptors and Smad3, since it increases their expression as soon as $30 \mathrm{~min}$ of treatment. For longer treatments, TGF- $\beta 2$ exerted the opposite effect and downregulated TGF- $\beta$ receptors (after $24 \mathrm{~h}$ of incubation) as well as Smad3 (after $3 \mathrm{~h}$ of incubation). Independent from incubation time the expression of Smad7 was upregulated by TGF- $\beta 2$ (Fig. 8a).

Furthermore, western blot analysis showed that T $\beta$ RII is downregulated after $24 \mathrm{~h}$ whereas $T \beta R I$ protein expression is decreased as soon as $1 \mathrm{~h}$ after TGF $\beta 2$ treatment. In addition, as expected, TGF- $\beta 2$ induced Smad2/3 phosphorylation. Expression of actin filament was slightly increased at the presence of TGF- $\beta 2$ (Fig. 8b).

Modifications of gene expression under TGF- $\beta 2$ treatment could be due to an increased degradation rate and/or a reduced transcription. Inhibition of de novo transcription clearly showed that TGF- $\beta 2$ reduced the mRNA half-life of both TGF- $\beta$ receptors. Indeed, the T $\beta$ RI half-life is about 20 min but was reduced to $10 \mathrm{~min}$ when chondrocytes were incubated with TGF- $\beta 2$, and the T $\beta$ RII mRNA half-life is 45 min for control cells and was reduced by almost $80 \%$ after TGF- $\beta 2$ treatment.

\section{Discussion}

Cartilage, a highly specialized tissue, sustains compressive load by cushioning the bones at joints, and by providing almost frictionless condition for joints to reduce wear. Cartilage as an avascular tissue has poor repair capacity and thus any damage or degradation on this tissue can cause pain, complexity in mobility and adversely affect daily life.

Monolayer culture of the primary chondrocyte resulted in dedifferentiation of cells and production of stress fibers. This characteristic was prevented by 3D chondrocyte culture (Multilayer Culture).

To our knowledge, so far, there are only few surgical options for treatment of chondral or osteochondral lesions of the hip. One such treatment is that of ACI which has been used frequently for treatment of knee cartilage defects with good outcomes, but there is probably only one or no use of ACI for the hip. It is our recommendation that collagen (type-I) gel (or patches) be used for prior chondrocyte implantation.

Another application of this research output/findings is $3 \mathrm{D}$ scaffold design which is a critical and essential part of tissue engineering. Our results from detachment assay suggested clearly that TGF- $\beta 2$ will decrease mechanical strength and biological interactions of chondrocyte culture, but it could have different effect when manipulated with other proteins.

TGF- $\beta 2$ increased cell length of chondrocyte, but decreased its proliferation rate and the wound healing process. TGF- $\beta 2$ also decreased cell adhesion ability to the surface of the culture flask which could be a sign of decrease in cell anchoring agent/ligands and proteins required to cell-cell and cell-ECM adhesion.

Our research shows that TGF- $\beta 2$ exerts a differential effect on the transcription of genes implicated in the Smads pathway. While TGF- $\beta 2$ upregulates its receptors and Smad3 for short incubation (at least at mRNA level), it downregulates them in the long term. In addition, it upregulates $\mathrm{Smad} 7$ and does not significantly alter Smad 2 and Smad4 expression. This positive and negative feedback loop of the TGF- $\beta 2$ pathway induces differential response of chondrocytes to TGF- $\beta 2$. The mechanisms responsible for modulation of Smads and for TGF- $\beta$ receptor expression seem to be different.

We have established that, in primary chondrocytes, TGF- $\beta 2$ acts, at least in part, by strongly decreasing the mRNA stability of its receptors. This rapid 


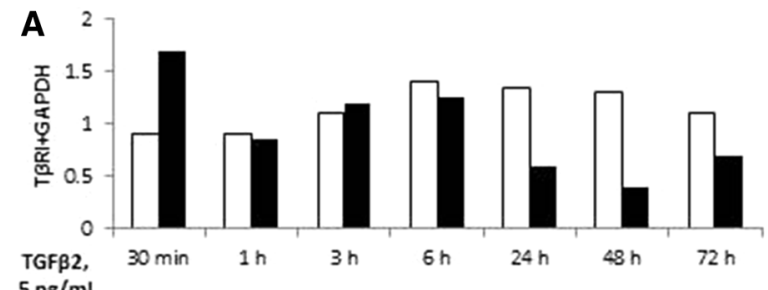

$5 \mathrm{ng} / \mathrm{ml}$
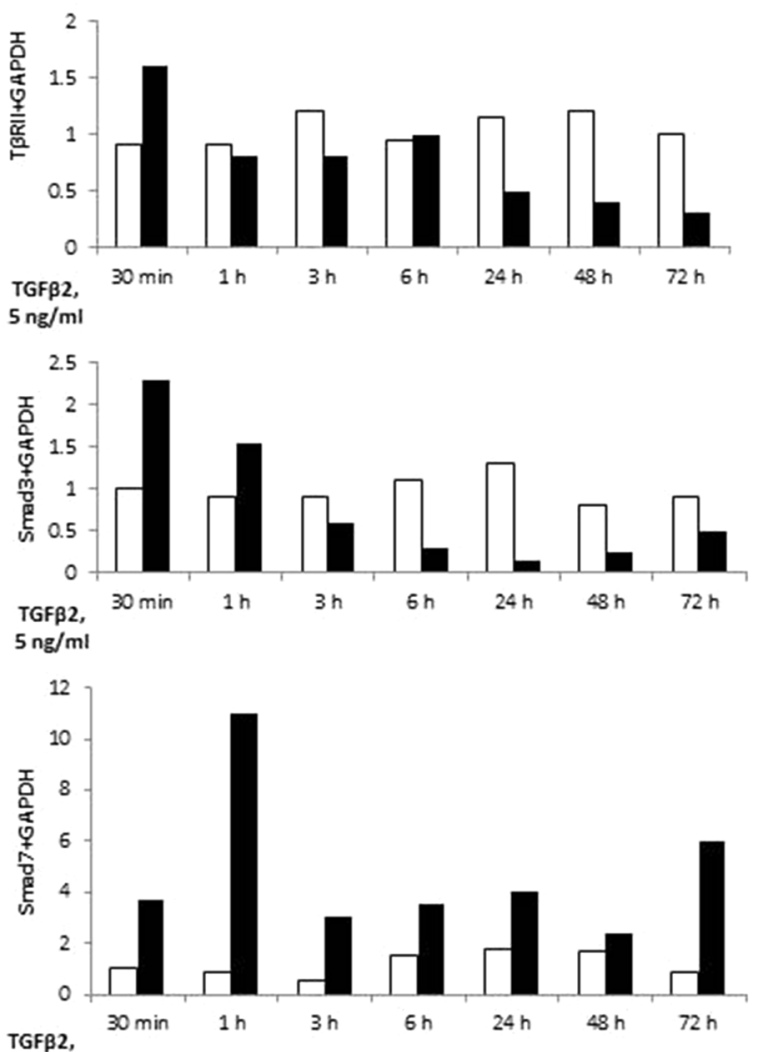

$5 \mathrm{ng} / \mathrm{ml}$

Fig. 8 Effect of TGF- $\beta 2$ on expression of T $\beta R I$, T $\beta$ RII, Smad2/3, actin and phosphorylated Smad2/3 protein analysed by RT-PCR and western blot technique. a Articular cartilage chondrocytes were incubated with $5 \mathrm{ng} / \mathrm{ml} \mathrm{TGF-} \beta 2$ for different times. At the end of incubations, T $\beta$ RI, T $\beta$ RII, Smad 3 and Smad7 mRNA levels were assayed by RT-PCR. b In addition,

turnover potentially allows the receptor rate to change rapidly in response to its own ligand. We cannot, however, exclude the possibility that TGF- $\beta$ downregulates its receptors also at the transcriptional and translational levels.

Concerning Smad effectors, we established that the downregulation of Smad3 mRNA expression in TGF$\beta 2$ treated chondrocytes was not due to decreased transcript stability, suggesting a transcriptional effect of TGF- $\beta 2$.
B

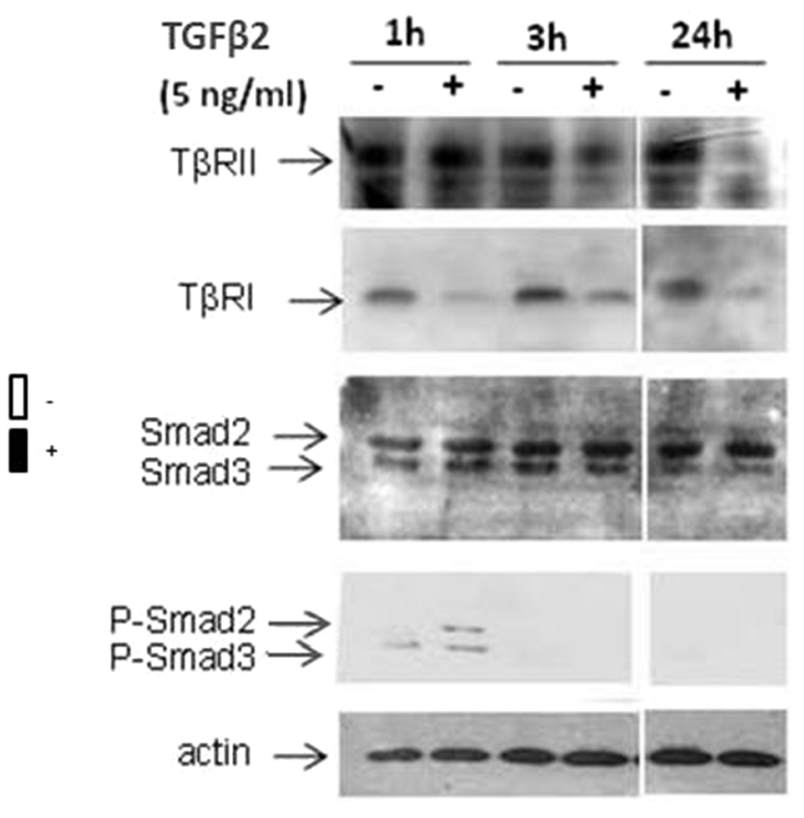

T $\beta$ RI, T $\beta$ RII, Smad2/3 and phosphorylated Smad2/3 protein expression were analyzed by western blot analysis. As control for equal loading, $\beta$-actin was also run in each blot. The modulation of mRNA expression was expressed as the percentage of controls after normalisation to the GAPDH signal

In contrast to $\mathrm{Smad} 3, \mathrm{Smad} 7 \mathrm{mRNA}$ expression was rapidly and markedly induced by TGF- $\beta 2$. Increased expression of the inhibitor Smad7 has been associated with inhibition of TGF- $\beta$ signaling. Smad7 could negatively regulate TGF- $\beta$ signaling; on one hand by inhibiting R-Smad activation by T $\beta$ RI or by enhancing T $\beta R I$ degradation in the cytoplasm, and on the other hand by disrupting the formation of the TGF$\beta$ induced functional Smad-DNA complex in the nucleus (Zhang et al. 2007). These TGF- $\beta 2$ induced 
modifications on expression of TGF- $\beta$ receptors and Smads may participate in the chondrocyte-phenotype changes observed in a pathology associated, at least in the first stage, with an increase in the TGF- $\beta 2$ level.

\section{Conclusions}

This work clearly demonstrated a successful and typical cell engineering of chondrocyte multilayers with our own model using isolated primary RAC by cell seeding, multiple 2D cell expansion and differentiation in vitro and without the use of bioreactor. Therefore, the same model can be used for isolation of HAC from clinically approved human biopsies for autologous chondrocyte implantation, and/or multilayer production for, e.g. cytotoxicity tests. Our model can also be used for direct expansion of the limited number of chondrocytes obtained from RAC or HAC, reaching higher densities similar to those used in conventional cartilage tissue engineering based on cells expanded by $2 \mathrm{D}$ cultures.

The effect of manipulated TGF- $\beta 2$ with other growth factors and/or proteins needs to be investigated to finalize the utilization of this growth factor and design of scaffolding in treatment of different types of arthritis.

\section{Compliance with ethical standards}

Conflict of interest The authors declare that they have no conflict of interest.

Open Access This article is distributed under the terms of the Creative Commons Attribution 4.0 International License (http:// creativecommons.org/licenses/by/4.0/), which permits unrestricted use, distribution, and reproduction in any medium, provided you give appropriate credit to the original author(s) and the source, provide a link to the Creative Commons license, and indicate if changes were made.

\section{References}

Balkwill FR (ed) (2000) Cytokine molecular biology: a practical approach. Oxford University Press, New York

Bhosale A, Richardson J (2008) Articular cartilage: structure, injuries and review of management. Br Med Bull 87:77-95

Cailotto F, Bianchi A, Sebillaud S, Venkatesan N, Moulin D et al (2007) Inorganic pyrophosphate generation by transforming growth factor-beta- 1 is mainly dependent on ANK induction by Ras/Raf-1/extracellular signal-regulated kinase pathways in chondrocytes. Arthritis Res Ther 9:122
Cohen K, Diegelmann RF, Landblad WJ (1992) Wound healing, biochemical and clinical aspects. W.B. Saunders Company, Philadelphia

Cubinskaya S, Hakimiyan A, Rappoport L et al (2008) Response of human chondrocytes prepared for autologous implantation to growth factors. J Knee Surg 21:192-199

Davidson EB, Scharstuhl A, Vitters E, Kraan PVD, Berg WVD (2005) Reduced transforming growth factor-beta signaling in cartilage of old mice: role in impaired repair capacity. Arthritis Res Ther 7:1338-1347

Docagne F, Gabriel C, Lebeurrier N, Lesné S, Hommet Y et al (2004) Sp1 and Smad transcription factors co-operate to mediate TGF-beta-dependent activation of amyloid-beta precursor protein gene transcription. Biochem J 383:393-399

Ferguson MWJ, O'kane S (2004) Scar-free healing: from embryonic mechanisms to adult therapeutic intervention. Philos Trans R Soc B Biol Sci 359:839-850

Galvani DW, Cowley JC (eds) (1992) Cytokine therapy. University of Cambridge Press, Cambridge, p 208

Gillogly SD, Voight M, Blackburn T (1998) Treatment of articular cartilage defects of knee with autologous chondrcoyte implantation. J Orthop Sports Phys Ther 28:241-251

Gorvy DA, Herrick SE, Shah M, Ferguson MWJ (2005) Experimental manipulation of transforming growth factor$\beta$ isoforms significantly affects adhesion formation in a murine surgical model. Am J Pathol 167:1005-1019

Han F, Gilbert JR, Harrison G, Adams CS, Freeman T et al (2007) Transforming growth factor $\beta 1$ regulates fibronectin isoform expression and splicing factor SRp40 expression during ATDC5 chondrogenic maturation. Exp Cell Res 313:1518-1532

Kaiser M, Haag J, Söder S, Bau B, Aigner T (2004) Bone morphogenetic protein and transforming growth factor beta inhibitory Smads 6 and 7 are expressed in human adult normal and osteoarthritic cartilage in vivo and are differentially regulated in vitro by interleukin-1 $\beta$. Arthritis Rheum 50:3535-3540

Kermani MG, Pham SH (2001) Role of cytokines and cytokine therapy in wound healing and fibrotic diseases. Curr Pharm Des 7:1083-1103

Khaghani SA, Denyer MCT, Youseffi M (2012) Effect of transforming growth factor- $\beta 1$ in biological regulation of primary chondrocyte. Am J Biomed Eng 2(1):1-8

Krauss G (2006) Biochemistry of signal transduction and regulation, 3rd edn. Wiley-VCH, London

Lawrence MR (2001) The Ank gene story. Arthritis Res 3:77-79

Liu X, Croker BA, Campbell IK, Gauci SJ, Alexander WS (2014) Key role of suppressor of cytokine signaling 3 in regulating gp130 cytokine-induced signaling and limiting chondrocyte responses during murine inflammatory arthritis. Arthritis Rheumatol 66(9):2391-2402

Livak KJ, Schmittgen TD (2001) Analysis of relative gene expression data using real-time quantitative PCR and the 2(- Delta Delta C(T)) method. Methods 25:402-408

Maitre CLL, Hoyland JA, Freemont AJ (2007) Catabolic cytokine expression in degenerate and herniated human intervertebral discs: IL-1 $\beta$ and TNF $\alpha$ expression profile. Arthritis Res Ther 9:77 
McIlwraith CW (2007) Anatomy and physiology of equine joints [Online]. Colorado State University, Colorado. Accessed 01 July 2007

Meyer U, Wiesmann HP (2006) Bone and cartilage engineering. Springer, Berlin, pp 25-33

Oka K, Oka S, Sasaki T, Ito Y, Bringas PJR et al (2007) The role of TGF- $\beta$ signaling in regulating chondrogenesis and osteogenesis during mandibular development. Dev Biol 303:391-404

Okazaki R, Sakai A, Nakamura T, Kunugita N, Norimura T, Suzuki K (1996) Effects of transforming growth factor beta $\mathrm{s}$ and basic fibroblast growth factor on articular chondrocytes obtained from immobilised rabbit knees. Ann Rheum Dis 55:181-186

Pohlers D, Beyer A, Koczan D, Wilhelm T, Thiesen H-J, Kinne RW (2007) Constitutive upregulation of the transforming growth factor- $\beta$ pathway in rheumatoid arthritis synovial fibroblasts. Arthritis Res Ther 9:59

Raftery LA, Sutherland DJ (2002) TGF- $\beta$ family signal transduction in drosophila development: from Mad to Smads. Dev Biol 210:251-268

Sefat F, Youseffi M, Khaghani SA, Soon CF, Javid F (2016) Effect of transforming growth factor-b3 on mono and multilayer chondrocytes. Cytokine 83:118-126

Soo C, Hu F-Y, Zhang X, Wang Y, Beanes SR et al (2000) Differential expression of fibromodulin, a transforming growth factor- $\beta$ modulator, in fetal skin development and scarless repair. Am J Pathol 157:423-433

Spagnoli A, O'rear L, Chandler RL, Granero-Molto F, Mortlock DP et al (2007) TGF- $\beta$ signaling is essential for joint morphogenesis. J Cell Biol 177:1105-1117

Stoff A, Rivera AA, Mathis JM, Moore ST, Banerjee NS et al (2007) Effect of adenoviral mediated overexpression of fibromodulin on human dermal fibroblasts and scar formation in full-thickness incisional wounds. J Mol Med 85:481-496

Tchetina EV, Antoniou J, Tanzer M, Zukor DJ, Poople AR (2006) Transforming growth factor- $\beta 2$ suppresses collagen cleavage in cultured human osteoarthritic cartilage, reduces expression of genes associated with chondrocyte hypertrophy and degradation, and increases prostaglandin E2 production. Am J Pathol 168:131-140

Thorp B, Anderson I, Jakowlew S (1992) Transforming growth factor-beta 1, -beta 2 and -beta 3 in cartilage and bone cells during endochondral ossification in the chick. Dev Co Biol 114:907-911

Van der Kraan PM, Van den Berg WB (2008) Osteoarthritis in the context of ageing and evolution. Loss of chondrocyte differentiation block during ageing. Ageing Res Rev 7:106-113

Yamashita A, Yonemitsu Y, Okano S, Nakagawa K, Irisa T (2002) Fibroblast growth factor-2 determines severity of joint disease in adjuvant-induced arhtiritis in rats. J Immunol 168:450-457

Yao JY, Wang Y, An J, Mao CM, Hou N et al (2003) Mutation analysis of the Smad3 gene in human osteoarthritis. Eur J Hum Genet 11:714-717

Zhang S, Fei T, Zhang L, Zhang R, Chen F et al (2007) Smad7 antagonizes transforming growth factor beta signaling in the nucleus by interfering with functional Smad-DNA complex formation. Mol Cell Biol 27:4488-4499

Zheng Z, Zhang X, Dang C, Beanes S, Chang GX et al (2016) Fibromodulin is essential for fetal-type scarless cutaneous wound healing. Am J Pathol 186:2824-2832 